\title{
Vitexin Anew Antihypertensive Drug (Isolated from prosopis farcta [Iraq endogenus] plants)
}

\author{
A. A. Al-Jeboory*1, A. I. AbdAllah ${ }^{2}$, B. S. Al-mgother ${ }^{3}$ \\ ${ }^{1}$ College of Pharmacy, Uruk University. Baghdad. Iraq \\ ${ }^{2 \nless 3}$ College of Medicine, Mustansyria University. Baghdad. Iraq
}

alialjeboory@yahoo.com

\begin{abstract}
Vitexin was isolated and identified from pods of prosopis farcta (Iraqi endogenous). In vitro and in vivo cardiovascular actions of vitexin were studied. Vitexin produced positive inotropic effect which was not related to B1 adrenergic receptor activation. Vitexin has a vasodilator activity and it could reverse thevasoconstrictor response of isolated pulmonary artery to potassium chloride and phenylphrine. Vitexin has produced a significant increase in ejection fraction in volunteers with mild heart failure. Also, vitexin has produced a significant increase in urinary flow and urinary sodium and potassium excretions in healthy and mild hypertensive volunteers, it's significantly reduced mean arterial blood pressure of the mild hypertensive volunteers. The positive inotropic effect of vitexin is most properly related to the inhibition of phosphodiesterase enzyme by vitexin. The vasodilator activities of vitexin could be mostly associated to the increase in cGMP (attributed to phosphodiesterase inhibitory effect of vitexin) and the activation of K+channels. The diuretic effects of vitexin could be attributed to the inhibition of $\mathrm{Na}-\mathrm{Cl}$ symporter system in the renal distal tubule. The most likely mechanisms of action of vitexin as a hypotensive compound are through its vasodilator and diuretic effects. So, this agent could be a best new antihypertensive drug compared with present antihypertensive drugs which are in the market now. In addition to that vitexin can be used in heart failure as cardiotonic drug.
\end{abstract}

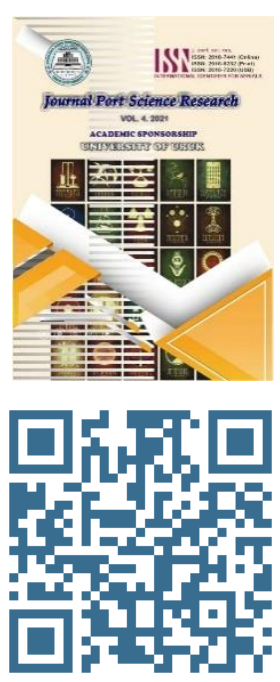

Crossref

$10.36371 /$ port/.2021.2

Keywords: Prosopis Farcta, Endogenous, Vitexin, Invitro, IR, UV,MS, and NMR spectrometry

\section{INTRODUCTION}

Substances derived from the medicinal plants remain the bases for a large proportion of the commercial medication used today for the treatment of heart disease, high blood pressure, asthma and other health problems. Prosopis Farcta (Figure 1 ) Species belonging to the genus Prosopis L. (Leguminosae, subfamily Mimosoideae), Arab name Shok or shauk or Kharnub; is a xerophytic woody shrub which grows widely in Iraq.

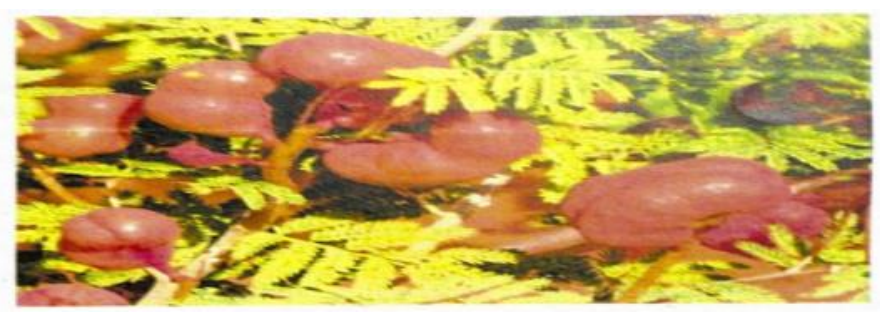

Figure (1) typical prosopis fareta (Iraqi endogens)

This plant has been reported to have nutritional and medicinal properties, Prosopis Farcta providing a range of products including timber, firewood, livestock feed, human food and beverages, fibers and tannins, Leaves and pods (Figure 2) of the plant have been reported to have some medicinal purpose such as in diarrhea, intestinal colic and hypertension, Vitexin is one of the main flavonoid components of the 'pods of prosopis Fareta, Flavonoids are polyphenol compounds that are present in many plants, and exhibit a variety of biological and pharmacological activities. To date, there are no published reports on the pharmacological effect of vitexin that is isolated trom prosopis fi This study is done in order to evaluate the pharmacological ettect lated from prosopis

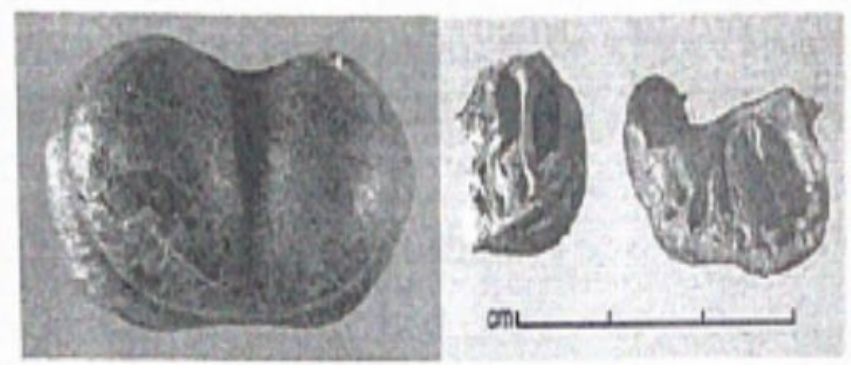

Figure (2) A. Pod, B. Pod opened revealing endocarp chambers

\section{Plant material}

Prosopis farcta pods were collected from east region of Iraq, Diala district. The pods were dried and identified by the staff of Iraqi national herbarium center in Abughreab. 


\section{Isolation of Vitexin}

Pods of prosopis farcta without seeds were air dried slightly above room temperature, grounded with a mortar and weighed. Then the product extracted at the room temperature with petroleum ether. The solvent was evaporated in vacuum at $20^{\circ} \mathrm{C}$ to give the dry extract. Vitexin in the dried extract was isolated and seperated with sephadex LH chromatography (elusion with methanol)

\section{Identification of Vitexin}

The vitexin was identified by IR,UV.MS, and NMR spectrometry (Figure 3 and 4)

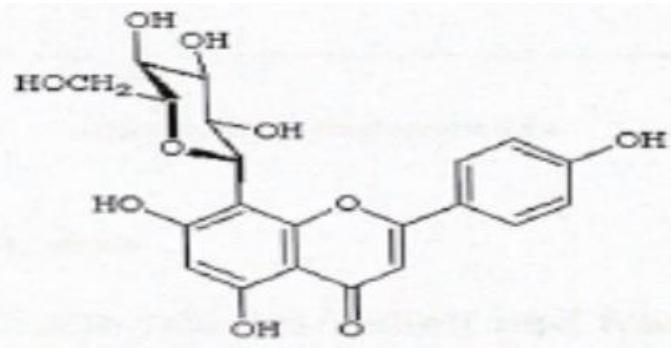

Figure (3) Vitexin (apigenin-8-glucoside)

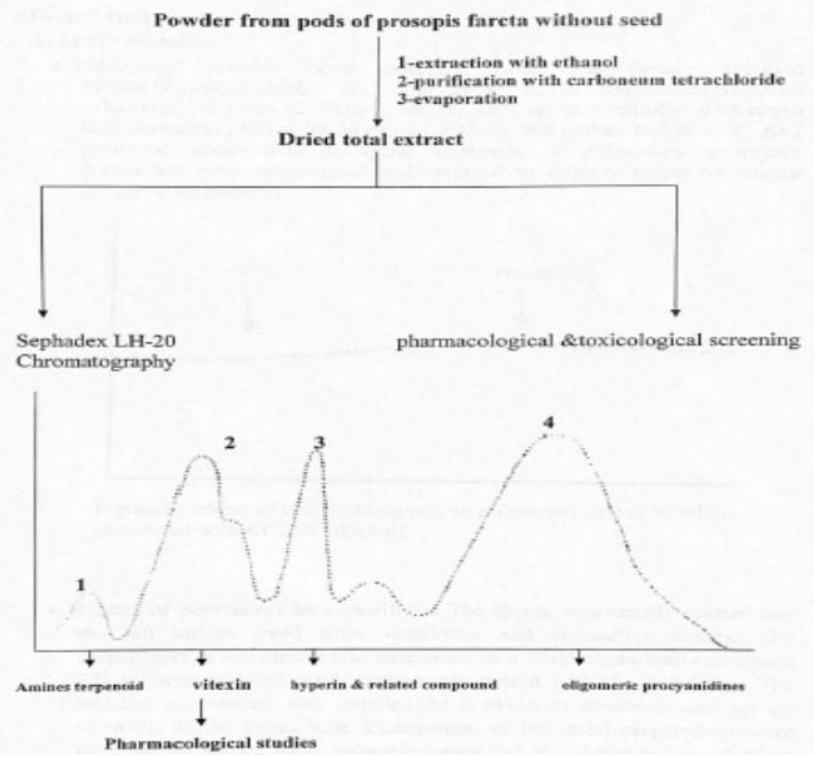

Figure (4) Row dior forthe extraction amd fractionation often rows

\section{Effect of vitexin on cardiovascular system}

A) In vitro studies. • Pulmonary arteries were obtained from the freshly _ sacrified rabbits, fibrillated with KCI and immersed in Krebs-Henseleit(KH) solution.spiral strips (2-3

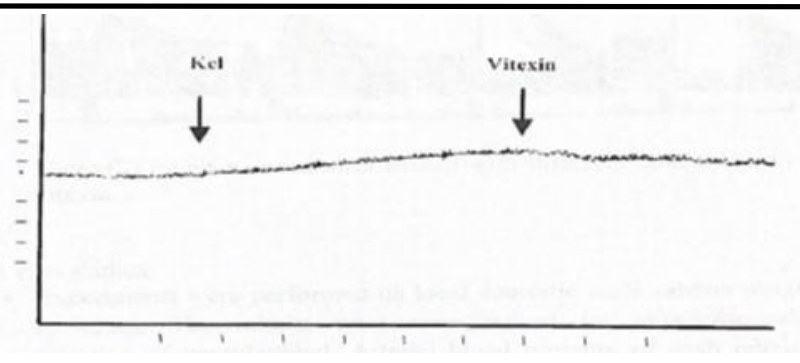

Figure(6) effect of vieexin $(60 \mathrm{pg} / \mathrm{ml})$ on pulmonary artery of rabbitpretreated with $K C K S O \mathrm{mEq}$ )

$\mathrm{cm}$ in length) were set up vertically in an organ bath containing $\mathrm{KH}$ solution gassed with air and maintained at $37^{\circ} \mathrm{C}$. $\mathrm{KCl}$ produced contraction of spiral segments of pulmonary artery,this contraction was antagonized and reversed to dilatory effect by vitexin $(60 \mathrm{ug} / \mathrm{ml})$ (figure-6-)

- Rabbits of both sexes were sacrificed. The thorax was rapidly opened and the left atrium freed from ventricular and connective tissues. The preperation of left atrium was suspended in a $30 \mathrm{ml}$ organ bath containing $\mathrm{KH}$ solution at $37^{\circ} \mathrm{C}$. And continuously gassed with $\mathrm{O} 2$ and $\mathrm{CO} 2$ The isolated preperation was impaled on a platinum electrode and set up vertically in the organ bath. Contractions of left atrial preperations were obtained by square wave pulses(frequncy 2-5 Hz, duration $5 \mathrm{~ms}$ of twice threshold voltage (usually 5-10 V) delivered by student stimulator.vitexin $(60 \mathrm{u} \notin / \mathrm{ml})$ produced positive inotropic effects on the isolated atrium,the cardiotonic effect of vitexin was not inhibited by using timolol $(0.5 \mathrm{mg} / \mathrm{kg})$ (figure-7-)

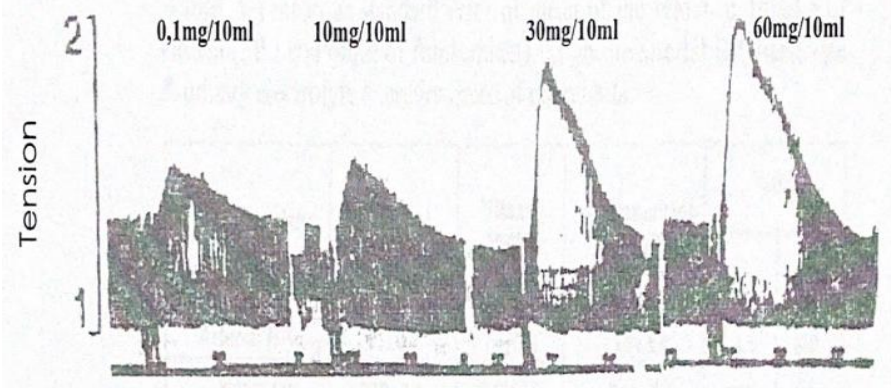

Figure(7) rabbit isolated atria treated with different concentration of Vitexin

\section{B) In vivo studies}

- Experiments were performed on local domestic male rabbits weighting $(1.5-2) \mathrm{kg}$. The rabbits were anaesthetized by intraperitoneal(I.P.) injection of pentobarbital. Arterial blood pressure of each rabbit was measured from the femoral artery connected to a mercury manometeron kymograph. The ear vein was cannulated for adminsration of drug solutions. The heart rate of the rabbit was recorderd from the blood pressure trace, after increasing the speed of recording paper to make the wave and pulsation apparent. Urine samples were 
collected via the urethra by catheterizaton of the urinary bladder by small size pediatric feeding tubes.

a) Intraperitoneal (I.P.) injection of $\mathrm{Img} / \mathrm{kg}$ of vitexin in the rabbits produced significant increases $(\mathrm{p}<0.01)$ in the urinary flow and urinary excretion rates of sodium and potassium in rabbits (table 1)

b) Intraperitoneal (I.P.) injection of $\mathrm{Img} / \mathrm{kg}$ of vitexin in the rabbits produced significant redaction $(\mathrm{p}<0.01)$ in the arterial blood pressure which was statistically similar to hypotensive.

Table 1) mean \& standard error of mean of the effect of Img $/ \mathrm{kg}$ of vitexin (1.P.) and $40 \mathrm{ug}$ of furosemide(I.P.) on the arterial $B P$, heart rate \& urinary electrolyte excretion rates of the rabbits.

\begin{tabular}{|c|c|c|c|c|c|}
\hline \multirow{2}{*}{ Parameters } & \multirow{2}{*}{ Control } & \multirow{2}{*}{$\begin{array}{l}\text { Vitexin } \\
\text { Imglkg }\end{array}$} & \multirow{2}{*}{$\begin{array}{c}\text { Furosemide } \\
40 \mathrm{pg} / \mathrm{kg}\end{array}$} & \multicolumn{2}{|c|}{ LSD } \\
\hline & & & & 0.05 & 0.01 \\
\hline Arterial BPmans & $83 \pm 4.8$ & $74 \pm 5.2$ & $72 \pm 4.4$ & 4.5 & 6.2 \\
\hline Heart rate & $230 \pm 3.1$ & $235 \div 10$ & $245+5.1$ & NS & NS \\
\hline $\begin{array}{l}\text { Urine flow } \\
\mathrm{ml} / \mathrm{hr} / \mathrm{Kg}\end{array}$ & $1.2 \pm 0.14$ & $1.5 \pm 0.14$ & $2 \pm 0.15$ & 0.195 & 0.24 \\
\hline $\begin{array}{l}\mathrm{Na}{ }^{*} \text { Exc. Rate } \\
\text { mEg/hr/kg }\end{array}$ & $107 \pm 3.8$ & $134 \pm 16.7$ & $202 \pm 7.8^{\circ}$ & 6.54 & 8,46 \\
\hline $\begin{array}{l}\mathrm{K}^{\prime} \mathrm{Exc} \text {. Rate } \\
\mathrm{mEq} / \mathrm{hr} / \mathrm{Kg}\end{array}$ & $2.87 \pm 0.13$ & $3.8 \pm 0.15$ & $5.9 \pm 0.16$ & 0.43 & 0.6 \\
\hline
\end{tabular}

effects of $40 \mathrm{yg} / \mathrm{kg}$ of furosemide, whereas the diuretic effects of effects of furosemide statistically $(p<0.01)$ was more potent than the diuretic effect of vitexin. Meanwhile the injection of this dose of vitexin caused no significant changes in heart rate of the rabbit (table l).

- Five volunteer aged 53 to 67 years suffering from chronic heart failure corresponding to NYHA class II attend the outpatients clinic of Al- yarmouk teaching hospital were included in this study trial.prior to the study, patient were informed about objectives and the study conducted and gave their written informed consent. At the first visit, a basic examination as well as recording of case history, health condition,previous/concomitant diseases, and medical treatment were done. Also ECG and echochardiography were done to each of them.it has been found that treatment with Vitexin capsule $20 \mathrm{mg} / \mathrm{twice}$ for weeks showed significant improvements in the subjective symptoms as well as an increase in exercise capacity, also the ejection fraction increases significantly $(\mathrm{p}<0.01)$. Figure (8)

- Thirty six volunteers aged 20 to 70 years of both sex suffering from mild hypertension attend the outpatients clinic of Al-yarmouk teaching hospital were included in this study trial.they

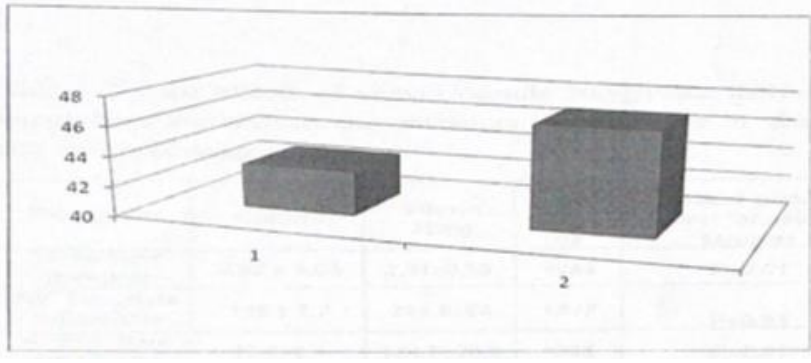

Figure (8) the means of ejection fraction before and after treatment with vitexin

were dicided in to 3 groups, each one consist of twelve patients.The first group were given vitexin capsule $20 \mathrm{mg} /$ twice daily for ten day, The second group were given candesartan capsule $15 \mathrm{mg} /$ daily for ten day \& The third group were given placebo capsule twice/ daily for ten day. Mean blood pressure of hypertensive volunteers were measured.Urine samples(per 12 hours) of each one were collected for analysis and compared with urine which was collected before taking prescribed medications.it has been found that vitexin capsule $20 \mathrm{mg} /$ twice daily produced a significant increase in urine flow and sodium and potassium excretion rate in mild hypertensive volunteers,moreover the same dose of vitexin significantly reduced mean blood pressure of hypertensive volunteers.(table 2 ) Figure $(9,10)$. The antihypertensive activity of vitexin compared with candesartan which is related to angiotensin II antagonist is seen in table 3 .

Table ( 2 ) the effects of vitexin capsule 20mg/twice daily on the urinary flow and sodium and potassium excretion rate in volunteers with mild hypertension.

\begin{tabular}{|c|c|c|c|c|}
\hline Parameters & Controi & $\begin{array}{c}\text { Vitexin } \\
30 \mathrm{mg}\end{array}$ & $\begin{array}{c}\% \\
\text { Chan } \\
\text { ge }\end{array}$ & $\begin{array}{c}\text { Statistical evaluation } \\
\text { t-test for paired } \\
\text { samples }\end{array}$ \\
\hline $\begin{array}{c}\text { Urine Flow } \\
\text { m/Kg/hr }\end{array}$ & $0.67 \pm 0.05$ & $2.31 \pm 0.35$ & +244 & $P-0.01$ \\
\hline $\begin{array}{c}\text { Na* Exc. Rate } \\
\text { mEq/Kg/hr }\end{array}$ & $115 \pm 7.7$ & 364.8154 & +217 & $P<0.01$ \\
\hline $\begin{array}{c}\text { K Exc. Rale } \\
\text { mEq/Kg/hr }\end{array}$ & $33.8+5.4$ & $134.5 \pm 20.3$ & +305 & $P<0.01$ \\
\hline
\end{tabular}

Table ( 3 ) The effect of vitexin on the mean arterial blood pressure, heart rate \& urine volume compared with effect of placebo and candesartan

\begin{tabular}{|c|c|c|c|}
\hline Group & $\begin{array}{c}\text { Mean blood } \\
\text { pressure }\end{array}$ & Heart rate & $\begin{array}{c}\text { Urine volume } \\
\mathrm{ml} / \mathrm{kg} / \mathrm{hr}\end{array}$ \\
\hline Vitexin & $95 \pm 3$ & $100 \pm 5$ & $2.4 \pm 0.3$ \\
\hline Candesartan & $100 \pm 3$ & $95 \pm 4$ & $1.9 \pm 0.04$ \\
\hline Control & $118 \pm 5$ & $90 \pm 3$ & $0.8 \pm 0.3$ \\
\hline
\end{tabular}

Figure (9) the means of systolic blood pressure before and after treatment with vitexin 


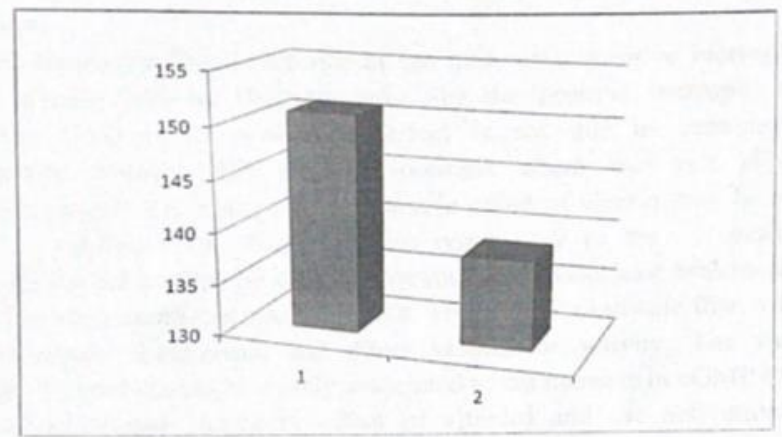

Figure (10) the means of diastolic blood pressure before and after treatment with vitexin

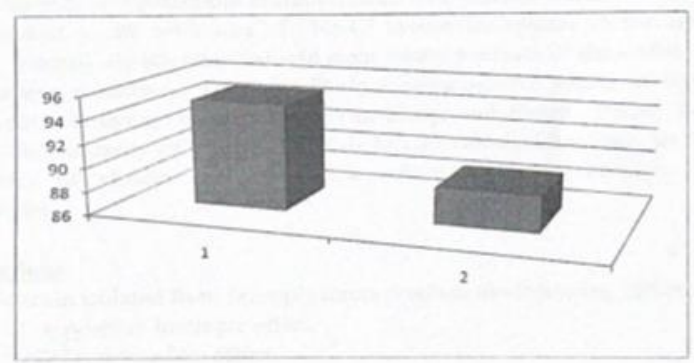

\section{DISCUSSION}

From our results we found that vitexin has quite clear positive inotropic effect, and its potency and its efficacy looks like the positive inotropic effect of adrenaline, however its cardiotonic effect is not due to activation of $\beta_{1}$ adrenoceptor ,because this positive inotropic effect was not blocked bytimolol(propranolol) 1 . The positive inotropic effect of vitexin may be attributed to the inhibition of $\mathrm{Na}, \mathrm{K}$ ATPase enzyme or to the inhibition of phosphodiesterase enzyme by vitexin. Vitexin had a vasodilator activity and could reverse the vasoconstrictor effects of $\mathrm{KCI}$. These results indicate that, viteein has $\alpha_{1}$ adrenoceptor antagonistic and direct vasodilator activity. The vasodilator activities of vitexin could be mostly associated to the increase in cGMe (attributed to phosphodiesterase inhibitory effect of vitexin) and the activation of $\mathrm{K}+$ - channels.

Vitexin in dose of $1 \mathrm{mg} / \mathrm{kg}$ in rabbits (I.P.), and $20 \mathrm{mg} / \mathrm{kg}$ twice daily (PO) in mild hypertensive volunteers, induced statistically significant rise in urine flow and urinary sodium and potassium excretion rates. The diuretic effects of vitexin could be attributed to the inhibition of $\mathrm{Na}-\mathrm{Cl}$ symporter system in the renal distal tubule. Vitexin signeficantly reduced mean.

blood pressure of the rabbits and mild hypertensive volunteers. The most likely mechanisms of action of vitexin as a hypotensive compound are through its vasodilator and diuretic effects. In addition to that the similarity of vitexin effect to that of candesartan leads us to think a possibility of vitexin antihypertensive effect could be through the same mechanism.

\section{CONCLUSION}

- Vitexin isolated from prosopis farcta produce the following etiects
a) Positive inotropic effect,
b) Diuretics like effect.
c) Vasodilator effect.
d) Blood pressure lowering effect.

- Due to the availability of prosopis farcta in large amount in our country, vitexin can be isolated from it and used in treatment of

a) Early stage of heart failure due to its positive inotropic, vasodilator and diuretic effects.

b) Mild hypertension due to its vasodilator and diuretic effects.

\section{REFERENCES}

[1] Tyler, V., Brady, L., \& Robbers, J. (1998). Pharmacognosy. Philadelphia: Lea \& Febiger. p. 255-263.

[2] Barisione, G., Baroffio, M., Crimi, E., \& Brusasco, V. (2010). Beta-adrenergic agonists. Pharmaceuticals. MDPI AG. https://doi.org/10.3390/ph3041016

[3] Burnstock, G. (1998). Cardiovascular biology of purines. Norwell (Mass.): Kluwer Academic Publishers. P. 342-358.

[4] DiBianco, R., Shabetai, R., Kostuk, W., Moran, J., Schlant, R. C., \& Wright, R. (1989). A Comparison of Oral Milrinone, Digoxin, and Their Combination in the Treatment of Patients with Chronic Heart Failure. New England Journal of Medicine, 320(11), 677-683. https://doi.org/10.1056/nejm198903163201101

[5] Giebisch, G., Klein-Robbenhaar, G., Klein-Robbenhaar, J., Ratheiser, K., \& Unwin, R. (1993). Renal and extrarenal sites of action of diuretics. Cardiovascular Drugs and Therapy, 7(1 Supplement), 11-21. https://doi.org/10.1007/BF00877954

[6] Stanton, B. A. (1990). Cellular actions of thiazide diuretics in the distal tubule. Journal of the American Society of Nephrology, 1(5), 832-836. https://doi.org/10.1681/asn.v15832 
[7] Townsend, R. R., \& Holland, O. B. (1990). Combination of converting enzyme inhibitor with diuretic for the treatment of hypertension. Archives of Internal Medicine. https://doi.org/10.1001/archinte.150.6.1175 